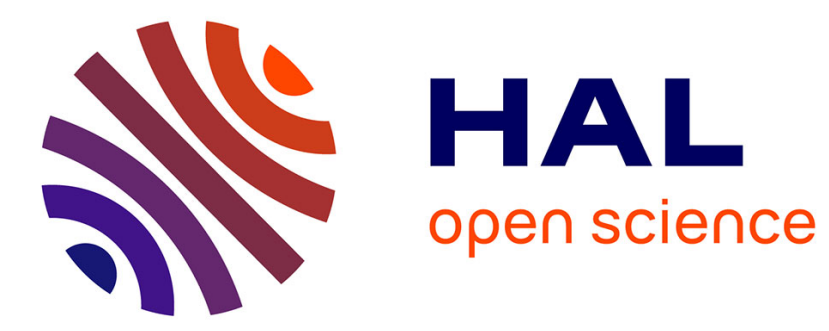

\title{
Potentiality of spectroscopic methods for the characterisation of dairy products. II. Mid infrared study of the melting temperature of cream triacylglycerols and of the solid fat content in cream
}

E Dufour, A Riaublanc

\section{To cite this version:}

E Dufour, A Riaublanc. Potentiality of spectroscopic methods for the characterisation of dairy products. II. Mid infrared study of the melting temperature of cream triacylglycerols and of the solid fat content in cream. Le Lait, 1997, 77 (6), pp.671-681. hal-00929555

\section{HAL Id: hal-00929555 \\ https://hal.science/hal-00929555}

Submitted on 1 Jan 1997

HAL is a multi-disciplinary open access archive for the deposit and dissemination of scientific research documents, whether they are published or not. The documents may come from teaching and research institutions in France or abroad, or from public or private research centers.
L'archive ouverte pluridisciplinaire $\mathbf{H A L}$, est destinée au dépôt et à la diffusion de documents scientifiques de niveau recherche, publiés ou non, émanant des établissements d'enseignement et de recherche français ou étrangers, des laboratoires publics ou privés. 


\title{
Original article
}

\section{Potentiality of spectroscopic methods for the characterisation of dairy products. II. Mid infrared study of the melting temperature of cream triacylglycerols and of the solid fat content in cream}

\author{
E Dufour, A Riaublanc \\ Laboratoire d'étude des interactions des molécules alimentaires, Inra, BP 71627, \\ 44316 Nantes cedex 03 , France
}

(Received 24 December 1996; accepted 13 May 1997)

\begin{abstract}
Summary - The purpose of the study was to investigate the relation between mid infrared spectra of cream recorded at various temperatures and the physical state of triacylglycerols in this temperature range. The spectra revealed differences as a function of temperature in the three regions considered: 1210 to $1130 \mathrm{~cm}^{-1}, 1770$ to $1710 \mathrm{~cm}^{-1}$ and 3000 to $2800 \mathrm{~cm}^{-1}$. The results of principal component analysis applied to the three sets of normalised spectral data showed a discrimination as a function of temperature according to principal component 1 . In order to predict the solid fat content, an equation was derived by taking the principal components as independent variable into account. Considering the methylene region, the correlation coefficient and the standard error were 0.996 and $0.62 \%$, respectively.
\end{abstract}

cream / solid fat content / melting temperature / mid infrared spectroscopy / multivariate analysis

Résumé - Intérêt des méthodes spectroscopiques pour la caractérisation des produits laitiers. II. Étude de la température de fusion des triglycérides de la crème et du taux de lipides solides au moyen de la spectroscopie moyen infrarouge. Ce projet sur la crème avait pour but l'étude des relations entre les spectres moyen infrarouge enregistrés à différentes températures et l'état physique des triglycérides. Pour les trois régions envisagées $\left(1210-1130 \mathrm{~cm}^{-1}, 1770-1710\right.$ $\mathrm{cm}^{-1}$ et $3000-2800 \mathrm{~cm}^{-1}$ ), les spectres présentent des allures différentes aux diverses températures de mesure. Les résultats des analyses en composantes principales appliquées aux trois séries de spectres normalisés montrent une séparation des échantillons en fonction de la température selon la composante principale 1 . La régression en composantes principales a été utilisée pour prédire le contenu en lipides à l'état solide aux différentes températures. Lorsque les données spectrales de la région des méthylènes sont considérées, le coefficient de corrélation et l'erreur standard sont respectivement de 0,996 et $0,62 \%$.

crème / taux de solide / température de fusion / spectroscopie moyen infrarouge / analyse multivariée 


\section{INTRODUCTION}

Since the early 1970 s, Fourier transform infrared spectroscopy (FTIR) has been available and it differs fundamentally from diffraction technology because it is based on interferometry. FTIR spectrometry has a number of advantages over the older instruments, including an improved signal-tonoise ratio, superior spectral resolution and wavelength accuracy. In addition, the use of an internal reference laser enables data manipulations such as spectral subtraction and the calculation of spectral ratios (van de Voort and Ismail, 1991).

Food products are mainly composed of fats, proteins, carbohydrates and moisture, all of which contribute to the spectrum obtained between $4000-400 \mathrm{~cm}^{-1}$. Components present at concentrations of less than $0.1 \%$ are however difficult to detect. Mid-infrared is widely used for qualitative and quantitative applications. For example, the quantitative determination of protein, lipid and lactose in milk can be assessed using mid infrared spectroscopy (Biggs, 1972; van de Voort et al, 1992). Free fatty acids, cis and trans contents and iodine value of fats and oil can also be determined by FTIR spectroscopy (van de Voort, 1992, 1995).

Most of the absorption bands in the mid infrared region, but not in the near infrared region, have been identified and attributed to chemical groups. The triacylglycerols ester linkage $\mathrm{C}-\mathrm{O}\left(\sim 1175 \mathrm{~cm}^{-1}\right), \mathrm{C}=\mathrm{O}\left(\sim 1750 \mathrm{~cm}^{-1}\right)$ group and acyl chain C-H $\left(3000-2800 \mathrm{~cm}^{-1}\right)$ stretch wavenumbers are commonly used to determine fat. In addition, many biophysical studies on the characterisation of model membranes such as liposomes have been reported. These approaches have been quite successful in characterising the organisation and dynamics of a lipid matrix. For example, the phase transition of phospholipids (sol-to-gel state transition) can be followed by mid infrared spectroscopy: increasing temperature results in a shift of the bands associated with C-H $(\sim 2850,2880$, 2935 and $2960 \mathrm{~cm}^{-1}$ ) and carbonyl stretching mode of the phospholipids. The plot of the maximum frequency of the $\mathrm{C}-\mathrm{H}$ band at about $2850 \mathrm{~cm}^{-1}$ versus the temperature allows the determination of the melting temperature of 1,2-dipalmitoyl-glycero-3-phosphocholine in fully hydrated multibilayers (Casal and Mantsch, 1984). The bands associated with lipid $\mathrm{C}-\mathrm{H}$ and carbonyl stretching mode also provide valuable structural and conformational information about the changes that occur in the acyl chains and interfacial moiety of the lipid molecule (Casal and Mantsch, 1984). These methods work very well for model systems containing only one or two phospholipid species. For more complex systems such as biological membranes or mixtures of triacylglycerols, the lipid bands broaden and it becomes more and more difficult to extract valuable information from the spectra.

Cream is an emulsion of triacylglycerols in a colloidal suspension of caseins. The lipids of cream originated from milk contain hundreds of triacylglycerol species (Jensen and Newburg, 1995). Melting of theses species occurs over a large temperature range, ie, between -30 and $+40^{\circ} \mathrm{C}$. Based on the melting temperatures, three groups of triacylglycerols are found in milk lipids. The first group has a low fusion temperature (LFT; -30 to $+10^{\circ} \mathrm{C}$ ), the second one shows a medium fusion temperature (MFT; +10 to $+20^{\circ} \mathrm{C}$ ) and, finally, the third group is characterised by a high fusion temperature (HFT; +20 to $+40^{\circ} \mathrm{C}$ ) (Timms, 1980 ). Triacylglycerols of the first group crystallise in an $\alpha$ polymorphic form, whereas in the two other groups crystals are in the $\beta$ ' form (Lavigne, 1995).

Solid fat content is an important quality control parameter in the edible fats and oils industry. Its main purpose is to determine the 'solids' content of a lipid system as a function of temperature. The functional characteristics of creams, butters, margarines 
and other fat blends depend largely on the value of this physical parameter. Solid fat content determinations have traditionally been based on dilatometry. Other commonly used methods are nuclear magnetic resonance and differential scanning calorimetry. Both of these methods are tedious and expensive to carry out (van de Voort et al, 1996). The purpose of this study was to investigate the relations between FTIR spectra of cream recorded at various temperatures and the physical state of triacylglycerols in this temperature range. The correlations observed indicate that FTIR spectroscopy allows the measurement of fat melting in mixtures of triacylglycerols and that this technique could be used for the determination of solid fat content in cream.

\section{MATERIALS AND METHODS}

The cream ( $30 \%$ fat) used in this study was a commercial cream and was purchased in a supermarket. The cream was kept at $4{ }^{\circ} \mathrm{C}$.

\section{Infrared spectroscopy}

Mid infrared spectra were recorded with a Nicolet Magna 550 FTIR spectrophotometer (Nicolet, Trappes, France) interfaced to a personal computer operating under Windows based Omnic 2.1 software. The instrument and sample compartment were purged with dry air to minimise water vapour and $\mathrm{CO}_{2}$ interferences. The spectrometer was equipped with a thermostated cell and the temperature was controlled by a Haake temperature controller. $\mathrm{CaF}_{2}$ windows separated by $13-\mu \mathrm{m}$ spacers in the demountable liquid thermostated cell were used to measure the spectra.

The spectra of cream samples were collected between 4000 and $650 \mathrm{~cm}^{-1}$ in steps of $2 \mathrm{~cm}^{-1}$ for temperature ranging between 8 and $60^{\circ} \mathrm{C}$, and rationed against an air background to produce an absorbance spectrum for each temperature. For each spectrum, a total of 200 scans were coadded. Between the acquisition of two spectra, the temperature of the cream was equilibrated for $5 \mathrm{~min}$.

\section{Mathematical treatments}

In order to reduce scattering effects, the data have been normalised by reducing the area under each spectrum to a value of 1 according to the formula (Bertrand and Scotter, 1992):

and

$$
c_{i}=A_{i} / \text { norm }
$$

$$
\text { norm }=\sqrt{\sum_{j=1}^{n} A j^{2}}
$$

where $c_{i}$ is the corrected value at wavelength $i, A_{i}$ is the absorbance at wavelength $i . A j$ is the absorbance at wavelength $j$ and $n$ is the number of data points for each spectrum.

Principal component analysis (PCA) is a multidimensional statistical method which optimises the description of the data with a minimum loss of information (Jolliffe, 1986). From a data set, PCA assesses principal components and their corresponding eigenvectors. The principal components are used to draw maps that describe the physical and chemical variations observed between the samples and make it possible to study them without any calibration step (Bertrand et al, 1987). Moreover, the eigenvectors are homologous to spectra and are called spectral patterns. Both positive and negative peaks of the spectral pattern can be interpreted as characteristic absorption bands of chemical constituents.

Principal component regression (PCR) has been used as a regression technique for a long time. The idea of PCR is to regress a response variable on principal components (Downey et al, 1987; Belleville et al, 1995). An equation of prediction of the solid fat content was derived by applying a multiple linear regression to the samples and using the principal components as variables. The efficiency of the equation was evaluated by the standard error (SE):

$$
S E=\sqrt{\sum_{i=1}^{n}\left(Y i-Y^{\prime} i\right)^{2} / n}
$$

where $\mathrm{n}$ is the number of spectra, $Y i$ and $Y^{\prime} i$ are the observed and predicted values for the sample $i$, respectively.

PCA and PCR software were written for PCs by Dr D Bertrand (LTAN, Inra Nantes, France). 


\section{Calorimetry}

The heat capacity measurements were carried out on a D 121 differential scanning calorimeter (Setaram, France) calibrated with indium and gallium. Cream samples of $110 \mathrm{mg}$ were introduced in cells which were pressure-sealed. The reference pan contained a similar quantity of water. Before analysis, samples were kept at $4{ }^{\circ} \mathrm{C}$. The samples in the cells were thermostated at $1{ }^{\circ} \mathrm{C}$ in the calorimeter during $10 \mathrm{~min}$ then heated at $3{ }^{\circ} \mathrm{C} / \mathrm{min}$ to $60^{\circ} \mathrm{C}$. The calorimeter was interfaced to a microcomputer.

\section{NMR experiments}

NMR experiments were performed on lipids purified from the cream. Cream was destabilised by freezing and thawing and then lipids were extracted by centrifugation at $70{ }^{\circ} \mathrm{C} .500 \mathrm{mg}$ of melted lipids were transferred into $10 \mathrm{~mm}$ diameter tubes. Solid fat content of samples was determined by H-NMR relaxometry (IUPAC, 1986) using a thermostated NMR spectrometer (Minispec PC120, $20 \mathrm{MHz}, 0.47 \mathrm{~T}$ ). The relaxation signal was recorded on a $\mathrm{PC}$ using a fast sampling card $(1 \mathrm{MHz})$. Signal recorded at $11 \mu \mathrm{s}$ corresponded to the solid phase protons and the liquid phase protons $\left(\mathrm{S}^{\prime}+\mathrm{L}\right)$. At $70 \mu$ s the signal is only due to the liquid phase protons (L). Since $11 \mu$ s was the deadtime of the receiver, a calibration factor $f$ must be applied to recalculate the response for total solid protons (S). This factor was determined using the indirect method of van Putte and van den Enden (1974) and, in this study, $f=1.37$.

Solid fat content (SFC) was then calculated according to the following equation:

$$
S F C=100 \frac{f\left[\left(L+S^{\prime}\right)-L\right]}{f\left[\left(L+S^{\prime}\right)-L\right]+L}
$$

\section{RESULTS AND DISCUSSION}

A number of 41 spectra were collected at various temperatures ranging between 8 and $60{ }^{\circ} \mathrm{C}$ to evaluate the potential of FTIR spectroscopy in determining the solid fat content of cream. It was postulated that the IR spectra of cream measured at different temperatures could serve as a basis for the pre- diction of the percentage of crystallised triacylglycerols. The spectrum recorded between 4000 and $650 \mathrm{~cm}^{-1}$ represents a superposition of all the mid-IR vibrational contributions of the individual triacylglycerols of the cream. The underlying principle is that the melting points or the fat solid content are determined by the molecular make-up of the cream, and that the amount of solids crystallising out at any given temperature is a function of both its fatty acid composition and distribution. Such information may be extracted from the mid infrared spectrum.

Figure 1 presents spectra of the cream obtained at various temperatures in the regions ranging between $1210-1130 \mathrm{~cm}^{-1}$, $1770-1710 \mathrm{~cm}^{-1}$ and $3000-2800 \mathrm{~cm}^{-1}$. These regions exhibited bands attributed to triacylglycerol ester linkage C-O $(\sim 1175$ $\left.\mathrm{cm}^{-1}\right), \mathrm{C}=\mathrm{O}\left(\sim 1750 \mathrm{~cm}^{-1}\right)$ group and acyl chain C-H (3000-2800 $\left.\mathrm{cm}^{-1}\right)$ stretching. This last spectral region was dominated by two strong bands at 2920 and $2850 \mathrm{~cm}^{-1}$, assigned to the methylene anti-symmetric and symmetric stretching modes (Cameron et al, 1980), respectively. Weaker bands resulting from the asymmetric and symmetric stretching modes of the terminal methyl groups were also present at 2956 and 2870 $\mathrm{cm}^{-1}$. For the three regions considered, the spectra showed different shapes as a function of temperature. In the ester linkage region, the maximum frequency at $1163 \mathrm{~cm}^{-1}$ and the shoulder at $1168 \mathrm{~cm}^{-1}$ were shifted upon heating to $1155 \mathrm{~cm}^{-1}$ and $1143 \mathrm{~cm}^{-1}$, respectively. A shift of the $\mathrm{C}=\mathrm{O}$ band from 1737 to $1743 \mathrm{~cm}^{-1}$ was also observed as the temperature increased from 8 to $50^{\circ} \mathrm{C}$. In addition, it was reported that the $\mathrm{C}=\mathrm{O}$ stretching vibration was sensitive to hydrogen bonding (Blume et al, 1988). Dehydrated films of pure phospholipids exhibit a single band at $1740 \mathrm{~cm}^{-1}$. The spectrum recorded at $11{ }^{\circ} \mathrm{C}$ showed, in addition to the band at $1737 \mathrm{~cm}^{-1}$, a low frequency component at about $1720 \mathrm{~cm}^{-1}$ which can be associated 

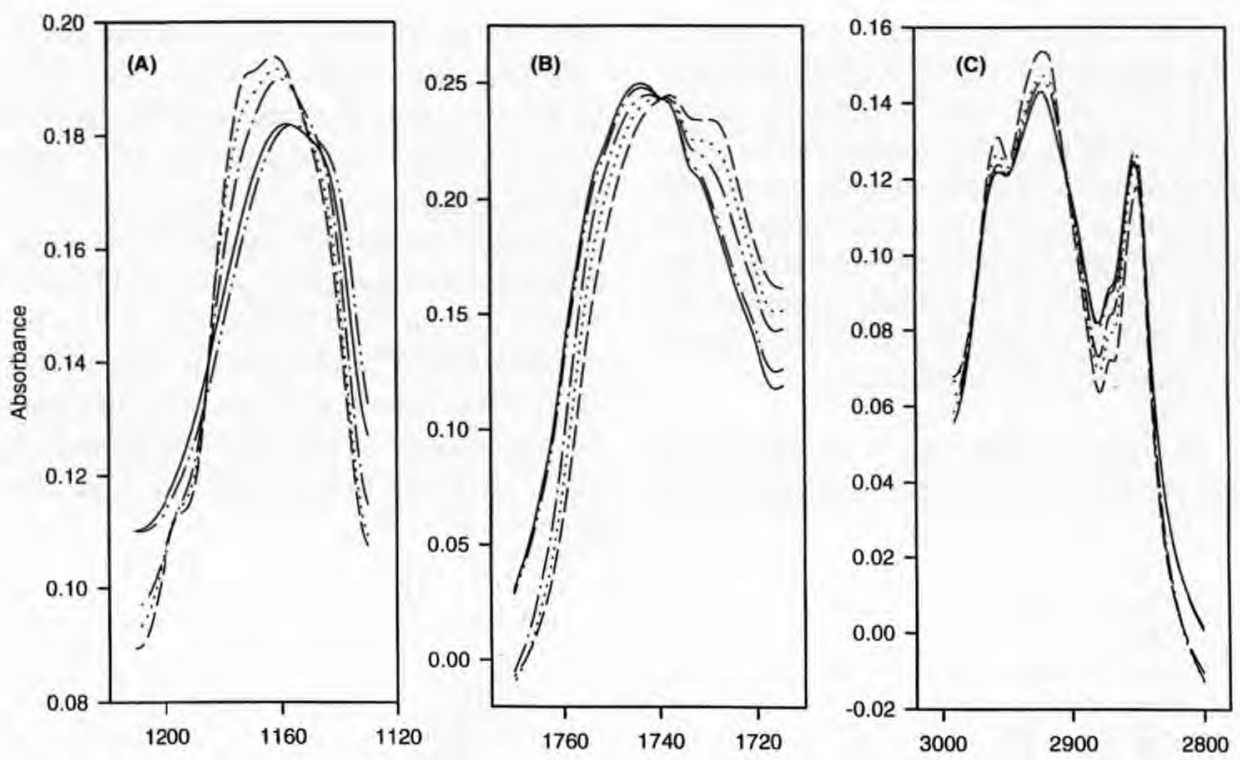

Fig 1. Mid-infrared spectra of cream in the regions of 1210 to $1130 \mathrm{~cm}^{-1}(\mathbf{A}), 1770$ to $1710(\mathbf{B}) \mathrm{cm}^{-1}$ and 3000 to $2800 \mathrm{~cm}^{-1}$ (C) recorded at different temperatures: $12(--), 20(\ldots), 30(-,-), 41(-\ldots-)$ and $50{ }^{\circ} \mathrm{C}(-)$.

Spectres moyens infrarouge de la crème dans les régions $1210-1130 \mathrm{~cm}^{-1}(\boldsymbol{A}), 1770-1710(\boldsymbol{B}) \mathrm{cm}^{-1}$ and $3000-2800 \mathrm{~cm}^{-1}(\boldsymbol{C})$ obtenus à différentes températures: $12(--), 20(\ldots), 30(-,-), 41(-, .-)$ et $50^{\circ} \mathrm{C}(-)$.

with the presence of hydrogen-bonded carbonyl groups (Blume et al, 1988). The shape of the spectra in the $3000-2800 \mathrm{~cm}^{-1}$ region changed also as a function of temperature, but the differences were smaller than those observed in the two other regions. It is well known, however, that the bands between 3000 and $2800 \mathrm{~cm}^{-1}$ associated with $\mathrm{C}-\mathrm{H}$ stretching modes are sensitive to the physical state of lipids. The shift of the band at about $2850 \mathrm{~cm}^{-1}$ is commonly used to follow the phase transition of phospholipids in model systems. For example, the frequency of the band associated with the symmetric stretching mode of $\mathrm{CH}_{2}$ groups $\left(v_{\mathrm{s}} \mathrm{CH}_{2}\right)$ shifts from 2850 to $2853 \mathrm{~cm}^{-1}$ during the melting of pure dipalmityl-phosphatidyl-choline bilayers (Casal and Mantsch, 1984). A sharp transition of the $v_{\mathrm{s}} \mathrm{CH}_{2}$ frequency is observed for the melting temperature of this phospholipid. From our data, the centre of gravity of the band associated with $v_{s} \mathrm{CH}_{2}$ was determined for each spectrum using Omnic software. The plot of the maximum frequency of $v_{s} \mathrm{CH}_{2}$ versus temperature did not allow, however, the determination of the gel-to-sol transition of the cream triacylglycerols (data not shown). Indeed, cream contains a huge number of different triacylglycerols. The large number of triacylglycerols of different fatty acid composition and distribution induce a broadening of the mid-IR bands associated with $\mathrm{C}-\mathrm{H}$ stretching in the spectra. It can explain the failure to derive directly the melting points of the cream from the maximum frequency of triacylglycerol $v_{\mathrm{s}} \mathrm{CH}_{2}$ bands.

Univariate analysis techniques are not appropriate for the study of complex mixtures such as food products. Multivariate analysis techniques such as principal component analysis (PCA) may allow the extra- 
ction of information related to the content of solid lipid or triacylglycerol melting points in the cream, from the mid-infrared spectrum. Using PCA, the spectra can be compared with each other in such a way that two similar spectra are represented by two neighbouring points on the similarity maps. This method is well suited to optimise the description of the data collection with a minimum loss of information.

In order to reduce the scattering effect, the spectra were normalised using equation 1

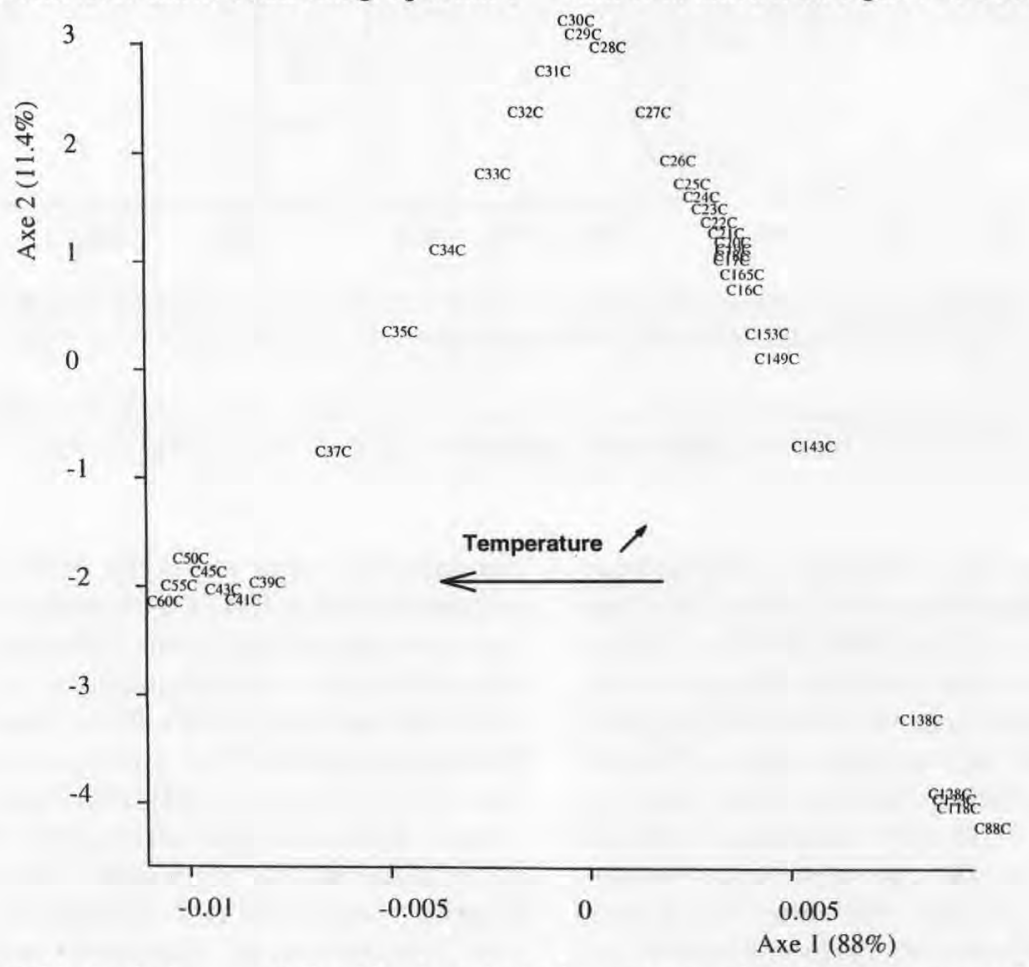

Fig 2. PCA similarity map defined by the principal components 1 and 2 for the spectral data of the $3000-2800 \mathrm{~cm}^{-1}$ region. Each label corresponds to a spectrum recorded at a fixed temperature. The spectra recorded at low temperatures are on the right side of the map and the spectra recorded at high temperature are on the left side of the map. Sample coding: the first letter is for cream, the digits are for temperature (for example, " $149 "=14.9^{\circ} \mathrm{C}$ and " $35^{\prime \prime}=35^{\circ} \mathrm{C}$ ) and the last letter is for $3000-2800 \mathrm{~cm}^{-1}$ region.

Carte factorielle 1-2 de l'analyse en composantes principales réalisée sur les spectres de la région $3000-2800 \mathrm{~cm}^{-1}$. Chaque étiquette correspond à un spectre enregistré à une température donnée. Les spectres acquis à basse température se situent du côté droit de la carte, alors que les spectres obtenus aux températures élevées se trouvent à gauche. Codage des échantillons : première lettre : " crème », les chiffres indiquent la température $\left(149: 14,9{ }^{\circ} \mathrm{C} ; 35: 35^{\circ} \mathrm{C}\right.$, par exemple) ; dernière lettre : région $3000-2800 \mathrm{~cm}^{-1}$. 

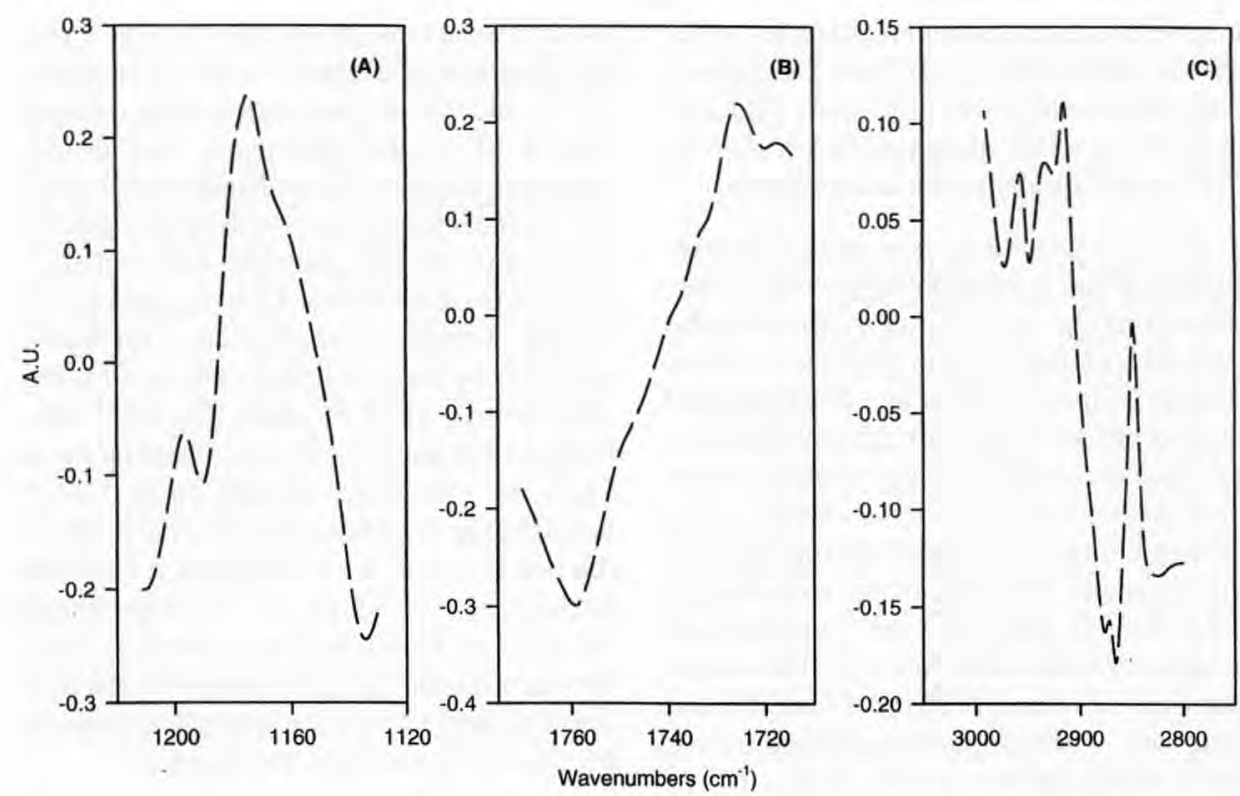

Fig 3. Spectral patterns corresponding to the principal component 1 . Regions between 1210 to $1130 \mathrm{~cm}^{-1}$ (A), 1770 to 1710 (B) $\mathrm{cm}^{-1}$ and 3000 to $2800 \mathrm{~cm}^{-1}$ (C).

Vecteurs propres 1 des analyses en composantes principales réalisées sur les données spectrales correspondant aux régions $1210-1130 \mathrm{~cm}^{-1}(\boldsymbol{A}), 1770-1710(\boldsymbol{B}) \mathrm{cm}^{-1}$ et $3000-2800 \mathrm{~cm}^{-1}(\boldsymbol{C})$.

principal components took into account $99.2 \%$ of the total variation. A discrimination of the samples as a function of temperature was observed according to the principal component 1: at low temperature the scores were positive, while at high temperature the scores were negative. Similar results were obtained when PCA was applied to the spectral data recorded between $1210-1130 \mathrm{~cm}^{-1}$ and $1770-1710 \mathrm{~cm}^{-1}$. principal component 1 classified the samples as a function of temperature (data not shown). These results indicate clearly that the mid infrared spectra contain information on the physical state of triacylglycerols in cream. Moreover, the eigenvectors corresponding to the principal components are homologous to spectra and are called spectral patterns. They provide information about the characteristic absorption bands which explain the similarities of the sample observed on the maps. The spectral patterns corresponding to the principal component 1 for the 3 regions investigated are given in figure 3 . In the $1210-1130 \mathrm{~cm}^{-1}$ region, it revealed characteristic wavenumbers at 1135,1174 and $1190 \mathrm{~cm}^{-1}$. The spectral pattern of the first principal component showed an opposition between a positive peak at $1726 \mathrm{~cm}^{-1}$ and a negative one at $1759 \mathrm{~cm}^{-1}$ when the $\mathrm{C}=\mathrm{O}$ region was considered. Finally, for the methylene region, an opposition between a positive peak at $2956 \mathrm{~cm}^{-1}$ and a negative peak at $2865 \mathrm{~cm}^{-1}$ was observed. The peaks at $2865 \mathrm{~cm}^{-1}$ and $2956 \mathrm{~cm}^{-1}$ were attributed to the symmetric stretching mode of $\mathrm{CH}_{2}$ groups and to the asymmetric stretching mode of $\mathrm{CH}_{3}$ groups (fig 1), respectively. This opposition between the two bands showed that the absorbance at $2956 \mathrm{~cm}^{-1}$ 
decreased for increasing temperatures, whereas the absorbance at $2865 \mathrm{~cm}^{-1}$ increased with increasing temperature. Indeed, $\mathrm{A}_{2865} / \mathrm{A}_{2956}$ ratio increased from 0.56 to 0.78 for the temperatures investigated.

The peaks characterised in the spectral patterns of the principal components 1 correspond to the wavenumbers that are the most discriminant for the three sets of data. Since principal component 1 discriminated the spectra as a function of temperature, these bands could provide valuable structural information about the changes that occurred in the acyl chains during the melting of cream. The plots of the absorbances at 1174,1726 and $2865 \mathrm{~cm}^{-1}$ versus temperature are shown in figure 4 . The absorbances at 1174 and $1726 \mathrm{~cm}^{-1}$ varied in the same way with temperature. These curves showed four distinct regions. Below $13^{\circ} \mathrm{C}$, the absorbance remained constant. The increase of temperature from $13.5^{\circ} \mathrm{C}$ to $29^{\circ} \mathrm{C}$ induced a decrease of the absorbance. Then, the absorbance decrease went on between $29^{\circ} \mathrm{C}$ and $38^{\circ} \mathrm{C}$, but with a larger slope. Above $40{ }^{\circ} \mathrm{C}$, the absorbance was almost constant. The plot of the absorbance at 2865 $\mathrm{cm}^{-1}$ versus temperature was more complicated than the two previous one and showed six regions. Below $13^{\circ} \mathrm{C}$ and above 45 ${ }^{\circ} \mathrm{C}$, the absorbance at $2865 \mathrm{~cm}^{-1}$ remained roughly constant; as it was observed for the absorbances at 1174 and $1726 \mathrm{~cm}^{-1}$. Between 13.5 and $15^{\circ} \mathrm{C}$, the absorbance at $2865 \mathrm{~cm}^{-1}$ increased sharply from 0.0745 to 0.08 (fig 4 ). Above $15^{\circ} \mathrm{C}$, the slope of the line decreased and it remained constant between 15.5 and $26^{\circ} \mathrm{C}$. Another sharp increase of the absorbance was observed between 26 and $28^{\circ} \mathrm{C}$. It was followed by a line segment exhibiting a smaller slope in the $28-42{ }^{\circ} \mathrm{C}$ range of temperature.

The melting points and the solid fat content of the cream were determined by
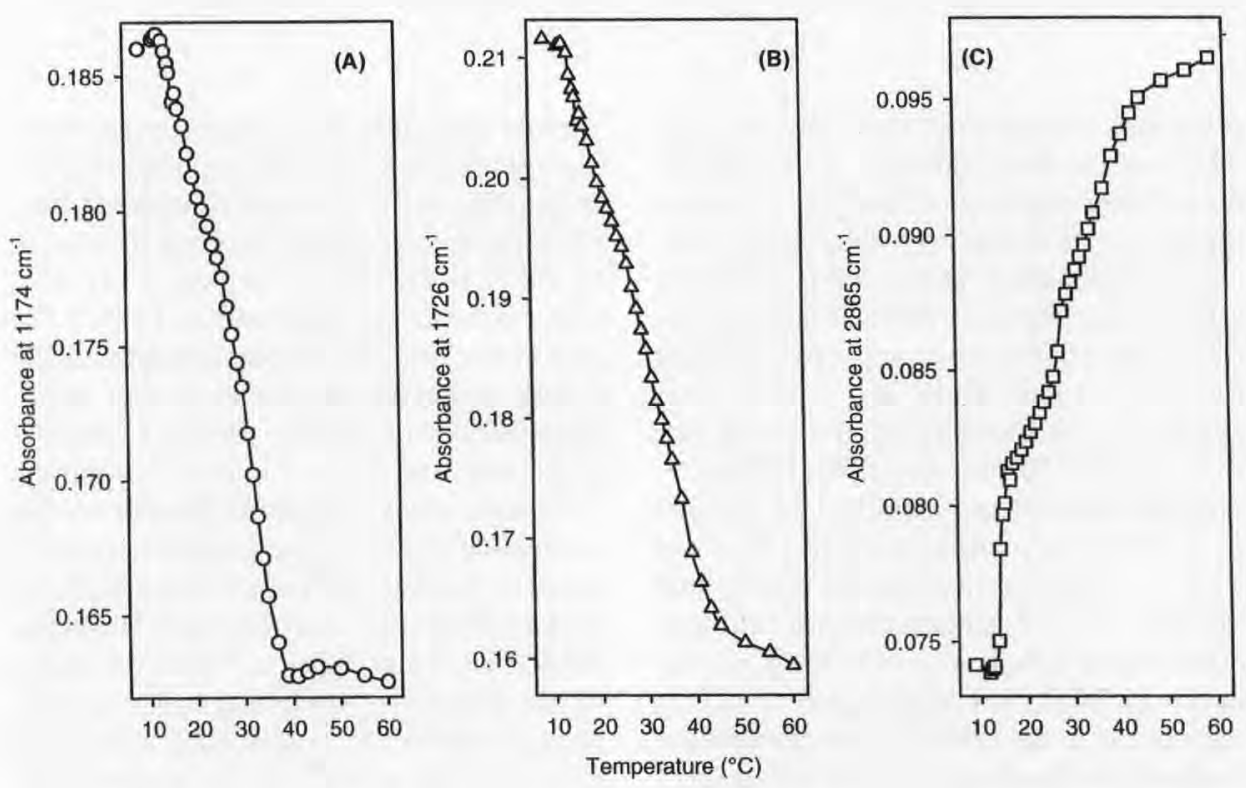

Fig 4. Plots of the absorbance at 1174,1726 and $2865 \mathrm{~cm}^{-1}$ versus temperature.

Variation de l'absorption à 1174,1726 et $2865 \mathrm{~cm}^{-1}$ en fonction de la température. 
differential scanning calorimetry (DSC) and low field nuclear magnetic resonance (NMR), respectively. As DSC measurements were performed on whole cream which contained about $70 \%$ of water, transitions at temperature below $0{ }^{\circ} \mathrm{C}$ were not investigated. As a consequence, the calorimetric data do not allow the calculation of the solid fat content using integration of the DSC curve. The obtained data provided only qualitative information on transitions in the lipids. In the temperature range $0-60{ }^{\circ} \mathrm{C}$, two endothermic peaks located at 22 and $33^{\circ} \mathrm{C}$ were observed (fig 5). The first peak corresponded to the fusion of the MFT triacylglycerols group whereas the second peak corresponded to HFT group (Lavigne, 1995). Complete melting of lipids was achieved at $45^{\circ} \mathrm{C}$. The correlations observed between FTIR and calorimetric data indica-

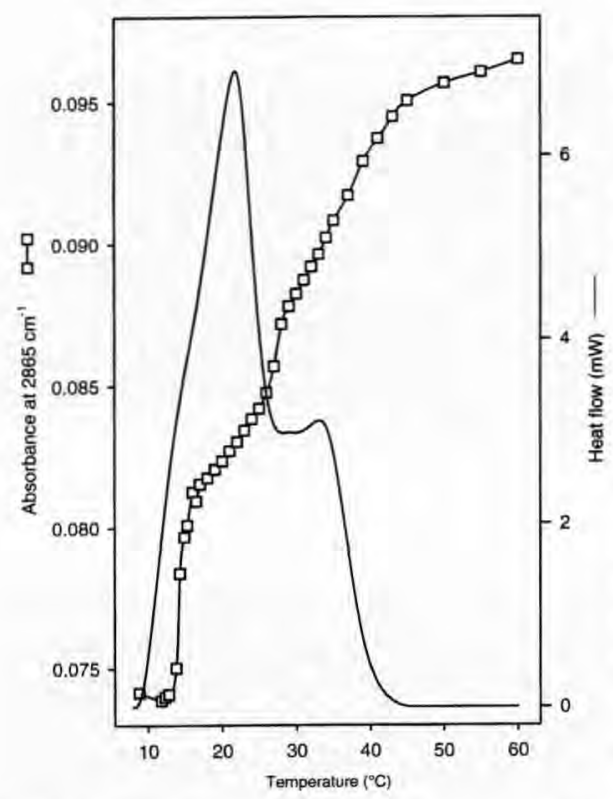

Fig 5. Cream thermogram and changes of the absorbance at $2865 \mathrm{~cm}^{-1}$ versus temperature.

Thermogramme de la crème et variation de l'absorption à $2865 \mathrm{~cm}^{-1}$ en fonction de la température. ted that there were relations between the changes of the absorbance at $2865 \mathrm{~cm}^{-1}$ and the physical state of triacylglycerols in the temperature range investigated (fig 5). The two segments of the absorption curve in the temperature ranges $15-26^{\circ} \mathrm{C}$ and $28-42^{\circ} \mathrm{C}$ corresponded with the two peaks of fusion observed on the thermogram.

The solid fat content (SFC) was measured by $\mathrm{H}-\mathrm{NMR}$ relaxometry at various temperatures. Indeed, the SFC were determined using equation 4 for temperatures ranging between 5 and $60^{\circ} \mathrm{C}$. The SFC determined at $5{ }^{\circ} \mathrm{C}$ and $35^{\circ} \mathrm{C}$ were $47 \%$ and $0 \%$, respectively. Between $5{ }^{\circ} \mathrm{C}$ and $35^{\circ} \mathrm{C}$, two regions were observed. SFC decreased linearly from $47 \%$ to $13 \%$ between $5{ }^{\circ} \mathrm{C}$ and $20^{\circ} \mathrm{C}$. Then, SFC continued to decrease up to $35^{\circ} \mathrm{C}$, but with a lower slope. Differences were observed in the final melting temperature determined by the two techniques. It was probably caused by polymorphic transition from $\beta^{\prime}$ crystals to a more stable form during temperature program in DSC (Lavigne, 1995). In addition, it should be mentioned that DSC and NMR do not measure the same parameters and, in this way theses techniques are complementary. DSC is a dynamic method which gives information about the transitions between different phases of lipids, whereas NMR allows quantification of liquid and solid phases at the equilibrium.

Since the comparison of calorimetry and FTIR data indicated that infrared spectra contained information about the physical state of tryacylglycerols in cream, an equation for the prediction of SFC was tentatively derived by applying a linear regression between absorbance at $2865 \mathrm{~cm}^{-1}$ and SFC determined by H-NMR. The linear relation between these two parameters was described by the equation:

$$
S F C=-1776.1 \times A_{2865}+161.8
$$

with a correlation coefficient $r^{2}$ of 0.96 and a standard error of $2 \%$. This large standard 
error could be explained by the fact that, in this linear regression, points were not randomly distributed but they showed a sinusoidal shape (data not shown). It appears once again that information is lost when only the absorbance at one wavenumber is used for the prediction. Univariate analysis techniques are not appropriate in this case. To obtain a better estimation of SFC from FTIR absorbance, it is essential to use the information contained in the whole spectra.

In order to develop the prediction equation, the solids data obtained by nuclear magnetic resonance were used for calibration. An equation of prediction of the SFC was derived by applying a multiple linear regression to the samples and taking the principal components as independent variables into account. Considering the $3000-2800 \mathrm{~cm}^{-1}$ region, the correlation coefficient and the $F$ Fischer test were 0.996 and 1862 , respectively. The equation of prediction was therefore significant at a probability level of $95 \%$. Moreover, the SE was $0.62 \%$ and confirmed that the methylene region of the mid infrared spectra is useful for SFC determination. The principal components were introduced into the equation in the following order: $1,5,3,7$ and 8 . The first principal component (principal component 1) that was taken into account allowed to discriminate the samples as a function of temperature. Similar results were obtained from the $1210-1130 \mathrm{~cm}^{-1}$ and $1770-1710 \mathrm{~cm}^{-1}$ regions. Equations of prediction allowed to estimate the solid fat content and confirmed the efficiency of mid infrared spectroscopy for predicting SFC in cream. A comparison of the observed values determined by NMR with the predicted values is shown figure 6 .

Although a definitive prediction equation of the solid fat content was not established, the results obtained in this study showed the potential of infrared spectroscopy for the prediction of physico-chemical parameters of dairy products. Mid infrared spec-

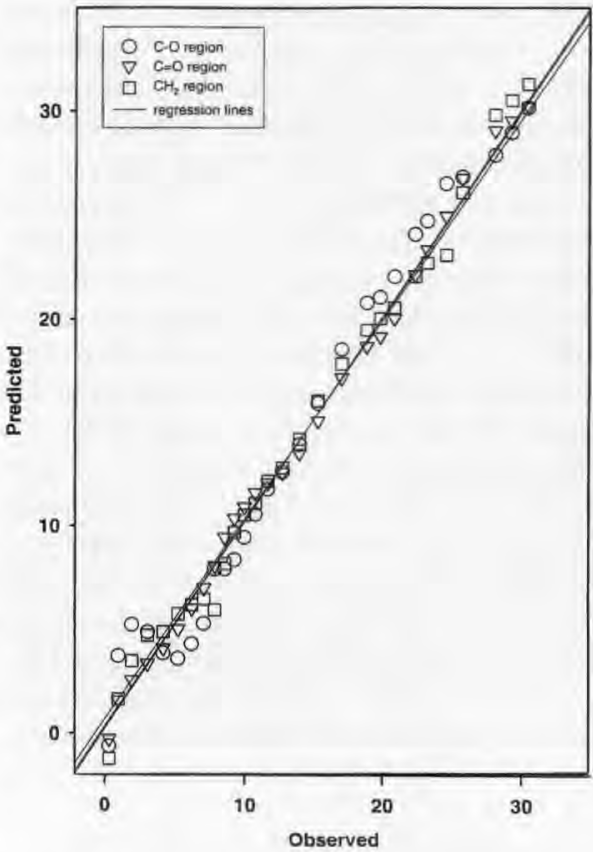

Fig 6. Prediction of solid fat content for the samples and comparison with observed values determined by NMR. Prediction using FT-IR data in the regions of 1210 to $1130 \mathrm{~cm}^{-1}(\mathrm{O}), 1770$ to $1710(\nabla) \mathrm{cm}^{-1}$ and 3000 to $2800 \mathrm{~cm}^{-1}(\square)$.

Prédiction de la matière grasse solide pour les échantillons et comparaison avec les valeurs observées déterminées par RMN. Prédiction utilisant les données infrarouge dans les régions 1210 to $1130 \mathrm{~cm}^{-1}(O), 1770$ to $1710(\nabla) \mathrm{cm}^{-1}$ et 3000 to $2800 \mathrm{~cm}^{-1}$ ( $\left.\square\right)$.

troscopy is well recognised as a primary tool for the identification of chemical compounds. The application of mid-infrared spectroscopy to the study of biological systems including foods has been limited, largely because the presence of water. The appearance of FTIR spectrometers and of appropriate data acquisition and software systems led to the development of rapid methods of food product analysis (van de Voort and Ismail, 1991). 


\section{ACKNOWLEDGMENTS}

We are grateful to J Davy (LPCM-INRA, Nantes) for the calorimetry measurements and to A Davenel (CEMAGREF, Rennes) for performing the NMR experiments.

M Subirade (Université Laval, Québec, Canada) is thanked for valuable discussions. D Bertrand (LTAN-Inra, Nantes) is acknowledged for the PCA and PCR software.

\section{REFERENCES}

Belleville C, Robert P, Hoebler C, Barry JL (1995) Infrared spectroscopic determination of poly(ethylene glycol) for nutritional studies. $J$ Agric Food Chem 43, 2672-2677

Bertrand D, Scotter CNG (1992) Application of multivariate analyses to NIR spectra of gelatinized starch. Appl Spectrosc 46, 1420-1425

Bertrand D, Robert P, Launay D, Devaux MF (1987) Application of principal component analysis to the determination of fat and protein content of milk by near-infrared spectroscopy. Rapid Analysis in Food Processing and Food Control Proc Euro Food Chem IV. 1-4 June, Loen, Norway

Biggs DA (1972) Precision and accuracy of infrared milk analysis. J Assoc Off Anal Chem 55, 488-492

Blume A, Hubner W, Messner G (1988) FTIR spectroscopy of ${ }^{13} \mathrm{C}=\mathrm{O}$-labeled phospholipids hydrogen bonding to carbonyl groups. Biochemistry 27 . 8239-8249

Cameron DG, Casal HL, Mantsch HH (1980) Characterization of the pretransition in 1,2 palmitoylsn-glycero-3-phosphocholine by FTIR spectroscopy. Biochemistry 19,3665-3672

Casal HL, Mantsch HH (1984) Polymorphic phase behaviour of phospholipid membranes studied by infrared spectroscopy. Biochim Biophys Acta 779, $381-401$
Downey G, Robert P, Bertrand D, Devaux MF (1987) Near infrared analysis of grass silage by principal component analysis of transformed reflectance data. J Sci Food Agric 41, 219-229

IUPAC (1986) Standard methods for the analysis of oils, fats, and derivatives. 6th edn. Pergamon Press, Oxford, UK

Jensen RG, Newburg DS (1995) Bovine milk lipids. In: Handbook of milk composition (RG Jensen, ed) Academic Press Inc, San Diego, 543-575

Jolliffe IT (1986) Principal Component Analysis. Springer, New York

Lavigne F (1995) Polymorphisme et transitions de phases des triglycérides. Applications aux propriétés thermiques et structurales de la matière grasse laitière anhydre et de ses fractions. Thèse, Université de Paris VII

Timms RE (1980) The phase behavior and polymorphism of milk fat, milk fat fractions, and fully hardened milk fat. Aust J Dairy Technol 35, 47-53

van de Voort FR (1992) Fourier transform infrared spectroscopy applied to food analysis. Food Res Int 25, 397-403

van de Voort FR, Ismail AA (1991) Proximate analysis of foods by mid-FTIR spectroscopy. Trends Food Sci Technol 2, 13-17

van de Voort FR, Sedman J, Emo G, Ismail AA (1992) Assessment of FTIR analysis of milk. J AOAC Int $75,780-785$

van de Voort FR, Ismail AA, Sedman J (1995) A rapid, automated method for the determination of cis and trans content of fats and oils by FTIR spectroscopy. $J$ Am Oil Chem Soc 72, 873-880

van de Voort FR, Memon KP, Sedman J, Ismail AA (1996) Determination of solid fat index by Fourier transform infrared spectroscopy. J Am Oil Chem Soc $73,411-416$

van Putte K, van den Enden (1974) Fully automated determination of solid fat content by pulsed NMR. $J$ Am Oil Chem Soc 51, 316-320 